\title{
PH.D.-AFHANDLING OM SCIENTOLOGY
}

Ved et offentligt forsvar for afhandlingen Rethinking Scientology: Cognition and Representation in Religion, Therapy and Soteriology, indleveret til bedømmelse ved Det Teologiske Fakultet, Aarhus Universitet, erhvervede Dorthe Refslund Christensen ph.d.-graden samme sted d. 18. november 1999. Bedømmelsesudvalget bestod af formand, lektor Jeppe Sinding Jensen (Arhus), professor Ingvild Gilhus (Bergen) samt professor Massimo Introvigne (Torino). Nedenfor bringes en oversat og redigeret udgave af Dorthe Refslund Christensens indledning og resumé ved forsvaret fulgt af en udvidet og redigeret udgave af Jeppe Sinding Jensens replik ved samme lejlighed.

\section{Indledning og resumé ved Dorthe Refslund Christensen}

Gennem de otte år, hvor jeg har forsket i Scientology, har det været sådan, at hvert af mine projekter har løst visse problemer og peget på nye empiriske aspekter, som kunne undersøges og herigennem motivere forsøg på at gennemarbejde nye teoretiske perspektiver. I hvert nyt projekt har jeg, så at sige, stået på skuldrene af et foregående projekt og forsøgt at arbejde mig igennem et særligt sæt af problemer, som hovedsageligt har været inspireret af det empiriske materiale. Afhandlingen er ingen undtagelse. Jeg er stolt af det arbejde, den repræsenterer, men jeg er samtidig opmærksom på - og ikke mindst inspireret af - den kendsgerning, at afhandlingen rejser nye problemer og peger mod nye interessefelter af såvel empirisk, teoretisk og metodologisk karakter. Jeg er taknemmelig for dette forsvars mulighed for at reflektere over og diskutere nogle af disse aspekter, og jeg håber at få lejlighed til at fortsætte min forskning inden for området $\mathrm{i}$ fremtiden.

Afhandlingen fokuserer på nogle af interrelationerne mellem terapi og religion $\mathrm{i}$ Scientologys soteriologiske ideer. Samtidig afsøger afhandlingen nye rammer for, hvordan dette fokus kan operationaliseres, samt hvordan de relevante resultater kan repræsenteres i en videnskabelig analyse.

Scientology, i sin nuværende form, er en individuel frelsesreligion, som tilbyder sine udøvere ideer og praksisser til hjælp for forståelse og ændring af forskellige eksistentielle betingelser vedrørende deres liv. Vejen til ultimativ åndelig frelse, Broen til Total Frihed, udgør et omfattende soteriologisk hierarki bestående af en lang række rituelle trin, som individet må afvikle i en nøje fastlagt rækkefølge for dermed at bevæge sig mod stadig højere eksistensformer og forøget erkendelse af sig selv og universet.

Nogle af disse rituelle erkendelsestrin inkluderer et terapeutisk system, Dianetics, der tilbyder sine udøvere en række ideer, som konstruerer kausalitet mellem symptom, forklaring og behandling i forbindelse med sygdom. På nogle niveauer er disse tera- 
peutiske aspekter integreret i Broen som nødvendige skridt på vejen til ultimativ frelse, mens de på andre niveauer betragtes som distinkte ideer og mål. På trods af den delvise integration, er de dianetiske elementer ikke assimileret i den scientologiske kontekst.

Historisk set blev Dianetics udviklet af L. Ron Hubbard i løbet af 1940'erne og fremlagt i bogen Dianetics. The Modern Science of Mental Health, som udkom forste gang den 9. maj 1950. Denne bog bliver på den ene side repræsenteret af Scientology som den ultimative repræsentation af dianetikkens terapeutiske ideer og praksis, og på den anden side er den blot én repræsentation af mange. Fra begyndelsen af 1950'erne videreudviklede Hubbard dianetikkens ideer og praksis og disse innovationer fik navnet Scientology i 1952. Mens Hubbard herefter i en årrække synes at have degraderet dianetikken pga. dens begrænsede rækkevidde og terapeutiske resultater og i stedet opprioriterede religionen Scientology og dens ultimative åndelige frelsesperspektiver, blev dianetikken i 1960'erne re-inkluderet i den soteriologi, som Hubbard innoverede og reinterpreterede frem til sin død i 1986. Når man studerer det meget omfattende skriftlige Scientology-materiale, implicerer dette et studium af en meget stor mængde meget forskellige repræsentationer skabt af Hubbard af såvel Dianetics som Scientology samt af deres interrelationer.

\section{Afhandlingens forskningshistoriske kontekst}

Tidligere forskning i Scientology, indtil 1994 primært foretaget af sociologer, tenderer mod at behandle forholdet mellem terapi og religion, Dianetics og Scientology, som et problem, der nødvendiggør en bestemmelse af, hvorvidt de terapeutiske eller de religiøse elementer er hyppigst repræsenterede i materialet. Hvis de terapeutiske elementer synes at være de mest prægnante, leder dette ofte (og oftest implicit) til spørgsmålet: Er Scientology virkelig en religion, når de terapeutiske elementer er så fremtrædende? Dette afspejler et syn på kulturelle fænomener som værende 'enten/eller', hvorfor en beskrivelse af dem skønnes at nødvendiggøre en beslutning til fordel for enten terapi eller religion. Interrelationerne mellem terapi (healing) og religion er meget ofte en del af de empiriske objekter, som er velkendte inden for religionshistorien $\mathrm{i}$ form af $\mathrm{fx}$ healingriter og andre riter. To forskellige eksempler på dette kunne være inden for såkaldte primitive religioner og kristendom. En stor mængde antropologiske feltstudier og religionshistoriske monografier omfatter således redegørelser for allehånde religioterapeutiske ideer og praksisformer. På trods af sådanne faglige traditioner, har mangt et forskningsbidrag om Scientology tenderet mod at diskvalificere Scientology som en "rigtig" religion på præcist dette interrelations-grundlag.

I min specialeafhandling, Fra Terapi til Religion (Christensen 1994), kritiserede jeg denne tilgang og påpegede, at flere af disse tidligere forskningsbidrag synes at lade fordomme og implicitte ideer om objektet fremfor eksplicitte teorier styre de empiriske analyser, som ofte leder til fremsættelsen af fordomsfyldte synspunkter, der bestemmer Scientology som værende en alternativ terapi - måske med kvasi-eller pseudoreligiøse elementer. Ydermere har disse diskvalifikationer været fremfort, uden at religion 
defineres eksplicit og uden at interrelationerne mellem Dianetics og Scientology analyseres grundigt. Specialeafhandlingen var et forsøg på at gå den modsatte vej: Med udgangspunkt i en analytisk definition af religion, adskilte jeg religion fra alle andre former for aktivitet (inklusive terapeutiske) med henblik på at demonstrere, at Scientology kan analyseres som en religion på trods af tilstedeværelsen af prægnante terapeutiske elementer. Denne form for tilgang repræsenterede imidlertid ligeledes en 'enten/eller-tilgang' - alle ædle hensigter til trods.

Med nærværende afhandling er forsøgt gennemført en tilgang, som undgår et enten/ eller i spørgsmålet om, hvorvidt Scientology er en terapi eller en religion, og som forsøger at demonstrere, at kun ved at generere en teoretisk ramme, som kan inkludere de dynamiske og komplekse relationer mellem terapi og religion i det scientologiske materiale, kan det scientologiske materiale præsenteres på en måde, som afspejler materialets kompleksitet, og som ikke ignorerer dele af materialet til fordel for entydighed. På basis af omfattende tekststudier og mange interviews og uformelle samtaler med scientologer fra overalt i verden, har det ligeledes været afgørende for mig at forsøge at udvikle en måde at analysere og repræsentere de relevante anliggender, som kunne udgøre en adækvat teoretisk og metodologisk basis for videre forskning $i$, hvordan scientologer rent faktisk bruger de scientologiske og dianetiske systemer.

\section{Afhandlingens overordnede metode}

Afhandlingens teoretiske ramme er etableret på baggrund af elementer fra nyere kognitiv teori inden for fagområder som psykologi, antropologi og videnskabsfilosofi med forskere som antropologen Pascal Boyer, antropologen Dan Sperber, videnskabsfilosoffen Robert N. McCauley, udviklingspsykologen Anette Karmiloff-Smith og religionshistorikeren E. Thomas Lawson. Sidstnævnte har været min medvejleder på projektet.

De kognitive teorier muliggør på mange måder genereringen af spørgsmål til et religiøst materiale, som ikke traditionelt har været stillet inden for religionshistorien, og som er innovative og produktive i udviklingen af nye tilgange til religion og kultur som komplekse fænomener, i særdeleshed $\mathrm{i}$ analysen af relationerne mellem forskellige kulturelle fænomener og af de dynamiske relationer mellem et religiøst system og dets udøvere.

Udover de kognitive teorier er inddraget forskning inden for medicinsk antropologi, repræsenteret ved forskere som antropologen Thomas J. Csordas og antropologen og psykiateren Arthur Kleinmann, lægerne David Sobel og Jette Sachs og socialantropologerne George M. Foster og Barbara Gallatin Anderson.

Pascal Boyer har i bogen The Naturalness of Religious Ideas (Boyer 1994a) og i en række supplerende artikler fremsat en kritik af antropologiske repræsentationer af religion og kultur, som jeg finder er gyldig for religionshistoriske ditto, "the theologistic bias", dvs. tendensen til at beskrive religiøse ideer som var de "shared, context-free general statements" (op.cit., 40). For det første, hævder Boyer, er det en 
tendens, at religiøse systemer analyseres og beskrives som var de konsistente og abstrakte systemer uden uintenderede indre modsætninger. For det andet implicerer denne form for repræsentation af religiøse systemer en tilskrivelse af betydning (meaning) til de repræsenterede abstraktioner, som ikke klart ekspliciterer, hvad eller hvem den aktuelle repræsentation tænkes at repræsentere. Beskrivelsen af religionen synes dermed at implicere, at en beskrivelse af fx en teksts betydning også er en beskrivelse af, hvad teksten betyder for de implicerede individer. System og individ bliver ét.

To perspektiver af Boyers kritik er forsøgt operationaliseret $i$ afhandlingens overordnede metodologi. For det første tages det udgangspunkt, at alle repræsentationer af Dianetics og Scientology produceret af Hubbard i årene 1950 til 1986 bør betragtes som 'singulare udsagn' og 'ad hoc redegørelser' produceret i en bestemt kontekst. For ikke at overlæsse analysen med irrelevante detaljer, er dette udgangspunkt systematiseret ved hjælp af udviklingspsykologen Anette Karmiloff-Smith og hendes begreb "representational redescription", således at Hubbards skriftlige repræsentationer ses som en serie af genbeskrivelser af én grundliggende oprindelig idé, "man is miserable and something can be done about it". Dianetikkens og scientologiens udvikling, som den er dokumenteret i materialet, er en fortsat genbeskrivelse af dette grundlæggende 'format'. Dette udgangspunkt for analysen af forholdet mellem Dianetics og Scientology, terapi og religion, $\mathrm{i}$ afhandlingen terminologiseret som "the inconsistency approach", sigter mod at undgå abstraktionen som mål for analysen - en konstruktion, som ikke ville kunne afspejle materialet og brugen af det i Scientology.

Den anden operationalisering af Boyers teologisme-kritik sigter mod at gøre klart, hvad og hvem analysen hævdes at repræsentere. Dette implicerer en distinktion mellem tre adskilte analyseniveauer, hvoraf de to første, som udgør det "systemiske niveau" er repræsenteret i afhandlingen: 1) L. Ron Hubbards repræsentationer af Dianetics og Scientology, 2) Scientology Kirkens repræsentationer af Hubbard og 3) individuelle scientologers repræsentationer. Afhandlingens analyser af de to systemiske niveauer i Scientology gør ikke krav på at repræsentere det tredie og individuelle niveau, idet nyere kognitive teorier, som er afhandlingens teoretiske fundament, har påpeget, at der ikke eksisterer nogen automatik i relationerne mellem et religiøst system og dets individuelle participanter. Eller sagt på en anden måde: Blot fordi et udsagn eller enkelte elementer af en ideologi er repræsenteret i en religions ideologiske og systemiske repræsentationer, implicerer dette ikke, at der rent faktisk findes individer inden for religionen, for hvem netop disse specifikke elementer er en aktiv del af det individuelle religiøse engagement og kognitive aktiviteter. Dette aspekt, som ikke er repræsenteret $\mathrm{i}$ afhandlingen, og som ville fordre en undersøgelse af individuelle scientologers mentale repræsentationer, finder jeg utroligt fascinerende og religionsvidenskabeligt interessant. 
Afhandlingen - kapitel for kapitel

I afhandlingens kapitel 1, Therapy and Religion: Outline of a New Approach, etableres en teoretisk ramme for forståelsen af religion og terapi, som kan generere en analyse af interrelationerne mellem de to, som ikke implicerer, at den ene prioriteres på bekostning af den anden. Som en grundlæggende præmis introduceres indledningsvist den boyerske kognitive tilgang til studiet af religion, som anser religions 'naturlighed' for at være et nødvendigt supplement til de (ofte implicitte) teorier om religionens 'kulturlighed', der ofte vægtes højere inden for antropologi og religionshistorie. Det grundlæggende argument for en sådan kognitiv tilgang er, at kulturelle repræsentationer såsom fx religiøse ideer er 'under-determinerede' af kulturel transmission. Denne under-determinering har tre vigtige implikationer: For det første "in most cultural environments there is very little explicit tuition, abstract instruction or commentary about what is denoted by religious terms" (Boyer 1994b, 396). For det andet når religiøs instruktion rent faktisk gives, bliver den oftest givet på en måde der er "too incomplete or inconsistent to constitute the basis for certain inferences" (op.cit., 397). Endelig for det tredie "the input [that are in fact given] is also essentially incomplete. Most religious notions could not be acquired and transmitted in the absence of certain unstated assumptions" (ibid.). Uden disse indbyggede antagelser ville de religiøse ideer ikke blot ikke kunne tilegnes - de ville være meningsløse. Disse grundlæggende ideer udgøres af menneskets grundlæggende intuitive ontologiske viden om verden, som er 'domænespecifik', dvs. forskellig fra ét kognitivt domæne til et andet. Fx tillægges forskellige egenskaber til forskellige ontologiske kategorier som dyr, menneske og objekt. Denne intuitive viden om verden, knyttet til forskellige domæner, er grundlæggende for menneskets omgang med verden, og den er et aktiv og en begrænsning $i$ konstruktionen, tilegnelsen og transmissionen af religiøse ideer, og udgør den 'skematiske' del af disse repræsentationer.

Foruden denne skematiske del udgøres religiøse ideer af 'ikke-skematiske ideer', som er 'kontraintuitive', dvs. de går imod den intuitive viden, som mennesket har om verden. Dette gør religiøse ideer tiltrækkende og opmærksomhedsskabende, anfører Boyer, og - anfører jeg - dette gør religiøse ideer 'potente' i nogle sammenhænge. Sagt med andre ord: Religiøse forklaringer af verden skønnes i nogle situationer at være mere produktive som forklaringspotentiale, nemlig i situationer hvor det abduktive inferenspotentiale baseret på intuitive ontologiske elementer vurderes at være utilstrækkeligt. I sådanne situationer inddrager individet de religiøse, kontraintuitive elementer som potent abduktivt materiale.

Denne tilgang implicerer, at man overordnet må fastholde, at religion og terapi involverer de samme grundlæggende kognitive mekanismer, at religion ikke er et særligt kognitivt domæne, og at religion ikke involverer en særlig mentalitet eller 'mode of thought' på baggrund af hvilket, det kan hævdes, at religion bør adskilles fra alle andre former for kulturel aktivitet. Selvom religioner, teologisk set, postulerer særlige kausaliteter mellem forskellige entiteter og deres handlinger og indbyrdes relationer, 
da involverer den faktiske brug af sådanne ideer stadig en variation af forskellige kognitive kausale strukturer forbundet til forskellige kognitive domæner og udløst i forskellige situationer, som kræver forskellige former for forklaring og inferens.

På baggrund af disse teorier defineres religion som en kulturel kategori: Religion er a shared set of concepts and ritual acts including the postulation of agents with special qualities. Denne definition tager udgangspunkt i en række kognitive teorier og eksperimenter, som har påvist at ideen om 'agency' er fundamental i menneskets kognitive omgang med verden. Agenter sætter handling igang, de får ting til at ske. I religion har disse agenter nogle særlige kvaliteter, og de er kontraintuitive. Definitionen ignorerer bevidst epistemiske elementer og specificerer ikke en specifik substans i de religiøse ideer. Den fokuserer udelukkende på de religiøse ideer og praksissers fundamentale natur ved at påpege implikationen af særlige agenstyper.

Derefter gives på baggrund af nyere teorier og distinktioner mellem forskellige sygdomskategorier inden for medicinsk antropologi en definition af terapi, som har til hensigt at etablere en tværkulturel forståelse af terapi, og som ikke diskriminerer mellem etableret og alternativ, vestlig og ikke-vestlig, virkningsfuld og virkningsløs terapi. Definitionen af terapi som kulturel kategori: A set of concepts and practices, the aim of which is the construction of causality between symptom, explanation and treatment in response to illness and sickness, specificerer ikke et særligt indhold af de terapeutiske ideer og praksisformer. Dermed er intenderet, at definitionen både kan omfatte så forskellige systemer som fx det biomedicinske system, shamanisme, krystalhealing, psykoterapi og Dianetics. Grundlæggende for denne definition er den tredelte kategorisering af sygdom, som skelner mellem 'illness', 'disease' og 'sickness' som henholdsvis den individuelle, den professionelle og den sociale/samfundsmæssige sygdomsoplevelse. Et andet grundlæggende træk er tilgangen til terapi, der fastholder terapi som den aktive respons på sygdom snarere end den objektive evne til strengt biomedicinsk at kurere sygdom, som det centrale og væsentlige.

Yderligere to definitioner introduceres, først definitionen af 'cultural repertoires', dvs. a cultural field distinct from other cultural fields by entertaining a certain set of concepts and practices by means of which a certain framework of interpretation, explanation and causality can be established and/or by designating a specified field of interest. Intentionen bag denne definition er at etablere et teoretisk apparat, som kan bruges til en sub-inddeling af en specifik kultur, og som kan informere en analyse af interrelationerne mellem forskellige sådanne 'sub-repertoirer', uden at den ene prioriteres fremfor den anden. I relation til terapi og religion kan denne definition give en forståelse af de 'potentielle overlapninger', som eksisterer mellem forskellige repertoirer. Herefter defineres soteriologi som a set of concepts according to which some present conditions of existence are compared to, and found inferior to, an ideal state of existence, and a set of practices related to these ideas, by means of which it is considered possible to reach an ideal state. These ideas and practices imply the postulation of agents with special qualities. Ideen bag disse definitioner er, at terapi undertiden kan overlappe religion ved at inkludere nogle af religionens konceptuali- 
seringer, mens religionen, defineret ved særlige agenstyper, kan overlappe det terapeutiske felt ved $\mathrm{fx}$ at inkludere ideer om sygdom i sin soteriologi. Disse kulturelle repertoirer og deres forskellige overlapninger demonstreres $i$ afhandlingens analyse.

I afhandlingens andet kapitel, The Source Material, præsenteres de forskellige skriftlige kilder, som er anvendt i analysekapitlerne. Dette materiale består af Technical Bulletins, de kronologiske bind I-XIII og emnebind 1-4; 26 grundlæggende Dianetik og Scientology-bøger og syv øvrige bøger. Hver bog præsenteres og relateres til Broen, den scientologiske soteriologi. Dette materiale udgør ca. 18.000 sider.

De øvrige materialer som præsenteres er videooptagelser af de store årlige Scientology-events, "The L. Ron Hubbard Birthday Event" og "The May 9th Event" (årsdagen for Dianetikbogens udgivelse) samt pamfletter, magasiner, tidsskrifter og hæfter. Der argumenteres for en pragmatisk tilgang til materialet fremfor en historiskkritisk tilgang, og forskellen mellem en pragmatisk og en historisk-kritisk tilgang til materialet analyseres. Den grundlæggende pragmatiske position, som gennemføres i afhandlingen, er, at det materiale, som hævdes at være Hubbards, analytisk må betragtes som Hubbards, hvis analysen skal give mening og kunne skabe rammen for en forståelse af, hvordan individer, som er engageret i Scientology såvel som systemet selv, opfatter og promoverer materialet.

Desuden giver kapitel 2 en introduktion til mit feltarbejde i Scientology Kirken i Danmark og USA, som er gennemført siden 1991.

Afhandlingens tredie kapitel, Therapy and Religion in the Process of Representational Redescription. A Chronological Analysis in a New Framework, fokuserer på Hubbards fortsatte genbeskrivelser af Dianetics (terapi) og Scientology (religion) og soteriologi samt på interrelationerne mellem disse elementer gennem årene 1950-86. Analysen tager sit udgangspunkt i Hubbards repræsentationer af Dianetics i dens oprindelige form repræsenteret i bogen Dianetics. The Modern Science of Mental Health fra 1950 og er kronologisk i sin opbygning og tematisk i sin fokus.

Det demonstreres empirisk og teoretisk, hvordan Hubbards oprindelige fokus var konstruktionen af en terapi til behandlingen af mental og psykosomatisk lidelse og endvidere, hvordan den grundlæggende monokausale forklaringsmodel etableredes og hvilke elementer og entiteter, som indgik. Det demonstreres endvidere, at Dianetics ikke omfattede postulater om 'agents with special qualities', hvorfor Dianetics kan siges at være i overensstemmelse med grundlæggende intuitiv ontologi uden elementer af kontraintuitiv karakter. Denne originale Dianetics blev gradvist potenseret ved inddragelsen af ideer om særlige agenter. I første omgang implicerede dette, at Hubbard kunne redegøre for særlige aspekter og perspektiver ved mental og psykosomatisk lidelse, som ikke hidtil havde kunnet forklares. På denne måde blev religiøse ideer centrale $\mathrm{i}$ den terapeutiske kontekst. Efterhånden ledte postulatet af agenter med særlige kvaliteter til en transcendering af den terapeutiske kontekst, og Hubbard vendte dianetikkens oprindelige terapeutiske mål ryggen og udviklede en soteriologi, hvis hensigt det var at frigøre menneskets sjæl og eksteriorisere den fra afhængigheden af det fysiske univers. Det, som begyndte som en potenseringen af en simpel 'gør-det-selv- 
terapi', blev dermed gradvist til en teori om, hvordan individet er blevet involveret $i$ eksistensbetingelser, som er ugunstige for hans eller hendes spirituelle udvikling. Sideløbende med denne teori udvikledes et meget komplekst soteriologisk hierarki, Broen. Denne udvikling foregår som en lang række af genbeskrivelser, i hvilke Hubbard hele tiden re-repræsenterede sine ideer og deres implikationer. Analysen demonstrerer, at hvor Hubbard fra begyndelsen af genbeskrivelsesfasen på mange punkter nedgjorde Dianetics og dens enkle terapeutiske aktiviteter, da blev disse elementer senere geninddraget. Dianetics' ideer, mål og terapeutiske praksis blev en del af den nye soteriologi. Dette implicerede udviklingen af nye teorier og nye rituelle teknikker, som raffinerede ældre ideer og teknikker. Det, som begyndte som en potensering af en terapi, blev til en religion, som i sin soteriologi inkluderer terapeutiske elementer. Selvom disse terapeutiske mål ikke længere blev betragtet som ultimative mål, holdt Hubbard aldrig op med at repræsentere dem som meget positive biprodukter.

Analysens strategi og opbygning er at repræsentere objektet, Hubbards kontinuerligt førte genbeskrivelser af det oprindelige format ('man is miserable and something can be done about it'), $i$ en stærkt accentueret kontekstualiseret form med henblik på at understrege repræsentationernes singulære, ad hoc karakter. Analysens intention er ikke at udelade den 'støj', som forstyrrer en 'glat' repræsentation af materialets overordnede linier, men snarere at fastholde 'støjen' som væsentlig. Analysen intenderer endvidere ikke at påpege teologiske sammenhænge, som ikke påpeges i Hubbards egne repræsentationer.

Det er muligt at påpege to sidestillede tendenser i materialet. For det første er Hubbards repræsentationer af dianetikkens og scientologiens ideer altid underdeterminerede, dvs. et emne eller aspekt behandles aldrig udtømmende eller tilstrækkeligt omfattende til at kunne siges at præsentere 'alt hvad der er at sige' om det pågældende. Dette giver en høj grad af fleksibilitet, idet både ældre og yngre repræsentationer dermed bliver gyldige referencer som det kulturelle repertoire og reservoir af ideer, som Scientology i dag udgør for sine udøvere. For det andet: Kanoniseringen af den rituelle praksis, den såkaldte Standard Teknologi, tenderer mod en stadig større standardisering, hierarkisering og rigiditet, som modsvarer den idémæssige fleksibilitet.

Afhandlingens fjerde kapitel, L. Ron Hubbard as Represented by the Church of Scientology, er en analyse af Scientology Kirkens initiativer med henblik på konstruktionen og fastholdelsen af L. Ron Hubbard som den eneste religiøse kilde (source) og legitimerende ressource i Scientology. To forskellige former for initiativer analyseres: centrale uddrag af den omfattende hagiografiske litteratur omhandlende Hubbards liv og virke og, for det andet, de organisatoriske og politiske initiativer til at fastholde Hubbard i positionen som religiøs og organisatorisk hovedperson.

Analysens hensigt er at give et perspektiv til forståelsen af Hubbards karakter af agent med særlige kvaliteter, som denne blev demonstreret i kapitel 3, og analysere hvordan Hubbard som religiøs innovator og frelser kommunikeres til scientologiens udøvere. Analysen peger på to sidestillede tendenser i Kirkens aktiviteter. For det første 
kan der argumenteres for en stadig stigende grad af de-humanisering og tekstualisering af Hubbard. Denne proces, som blev påbegyndt af Hubbard selv, betoner hans særlige kvaliteter og evner, og forholder sig til abstraktionen af Hubbard fra menneske til Standard Teknologi (de standardiserede rituelle teknikker). Den mest radikale konsekvens af denne proces er transformationen af Hubbards navne i deres forskellige udgaver til registrerede varemærker. For det andet understreger Kirken igen og igen, at Hubbard var et menneske, som havde stor omsorg for sine medmennesker, og som ønskede at hjælpe dem til et bedre liv. Disse to sider af Kirkens initiativer kommunikerer to forskellige budskaber, som supplerer hinanden. Hubbard som særlig agent peger på mulighederne for realisationen af individets potentiale, hvis han eller hun følger den af Hubbard angivne frelsesvej, mens fastholdelsen af Hubbard som menneske giver basis for identifikation med Hubbard.

Afhandlingens afsluttende kapitel, Concluding Summaries and Perspectives, er en opsummering af afhandlingens teoretiske og empiriske resultater. Desuden gives et kortfattet perspektiv, som peger på mulige fremtidige forskningsfoci.

\section{Konklusion}

Som nævnt $i$ denne forelæsnings indledning, giver ethvert forskningsprojekt visse svar på visse spørgsmål, men åbner (forhåbentlig) samtidig forskerens øjne for nye problemog interessefelter, påpeger nye spørgsmål, der bør stilles og nye teoretiske og metodologiske skridt, der må tages for at besvare sådanne spørgsmål. Det væsentlige for mig i relation til arbejdet med ph.d.-afhandlingen er, at jeg føler at have fundet en produktiv og adækvat måde at arbejde med det scientologiske materiale og at have flyttet mig selv et skridt væk fra den 'teologistiske' arbejdsfacon, som jeg havde i min specialeafhandling og i mine bøger. Eller sagt på en anden måde: Jeg er begyndt at lære, hvordan man stiller adækvate og interessante spørgsmål og er fuld af forhåbning om, at min fremtidige forskning vil bidrage til at forfine denne evne.

\section{Litteratur}

BOYER, PASCAL

1994a The Naturalness of Religious Ideas. A Cognitive Theory of Religion, Los Angeles and London.

1994b "Cognitive constraints on cultural representations: Natural ontologies and religious ideas" in Hirschfeld, Lawrence A. \& Susan A. Gelman, eds., Mapping the Mind. Domain Specificity in Cognition and Culture, New York.

CHRISTENSEN, DORTHE REFSLUND

1994 Fra Terapi til Religion. En religionshistorisk analyse af centrale begreber i henholdsvis Dianetics og Scientology med saerligt henblik på forskellene i diskurs og mål. Specialeafhandling. Institut for Religionsvidenskab, Aarhus Universitet. 


\section{Replik ved Jeppe Sinding Jensen}

Det er et markant bidrag, som Dorthe Refslund Christensen har givet til religionsvidenskaben og offentligheden med sine studier af Scientology. I særdeleshed er hendes ph.d.-afhandling informativ med en mængde viden om Scientology, som ikke har været kendt eller tilgængelig for den almindelige religionsvidenskab. Kendskab til Scientology har været en sag for nogle få specialister, heraf de fleste med samfundsvidenskabelig baggrund og interesse. Derudover har der været en mængde pseudo-viden i omløb, som har indgået i de utallige kontroverser mellem Scientology og de samfund, vel især europæiske, som har været kritiske over for 'bevægelsen' og hvor man mange steder har nægtet at anerkende Scientology som en religion. Dorthe Refslund Christensen siger ligeud, at Scientology er religion, og det har kostet hende nogle besværligheder - bl.a. i forbindelse med udgivelse af en bog om Scientology til undervisningsbrug. Jeg mener, at hun har helt ret i sit synspunkt og ganske banalt harmonerer det også med den interne selvforståelse i 'The Church of Scientology'; en selvforståelse, der omfatter mere end ønsket om skattefritagelse. Ligeledes fastslår Dorthe Refslund Christensen, at Scientology også omfatter terapeutiske ideer og praksisformer, nogle mere eksplicitte end andre, f.eks. som de er fremstillet i L. Ron Hubbards 'oprindelige' lære Dianetics, der senere blev mere (eller mindre) integreret i Scientology. Koblingen mellem religion og terapi findes vel i stort set alle de religioner, som en almindelig religionshistoriker (som jeg selv) er bekendt med. Det er ikke så nyt endda. Heller ikke sammenhængen, da enhver terapiform involverer en kosmologi. For Dorthe Refslund Christensen er det vigtigt at få denne sammenhæng understreget, og det især med adresse til den tidligere forskning i Scientology. Hun præsenterer Scientology som en religion, 'a shared set of concepts and ritual acts including the postulation of agents with special qualities', for dette findes også i Scientology. De fleste bidrag til forskningen omkring Scientology har stort set undladt at fokusere på indholdet i Scientology, men det gør så Dorthe Refslund Christensen til gengæld. Og hermed lancerer hun et substantielt bidrag også til den almindelige religionsforskning, for nu kan man bruge scientologisk materiale f.eks. også i religionsfænomenologien. Vigtigere, på det overordnede teoretisk-metodiske niveau, er det dog, at man her kan se 'en religions fødsel' i en historisk mere tilgængelig periode end for de fleste andre religioner. Tilmed med et meget stort kildemateriale. Det skal nok passe, når Dorthe Refslund Christensen opregner det, som hun har anvendt, til at omfatte 18.000 sider. Dertil kommer så et andet materiale i form af videobånd etc. Man kunne også inddrage alment tilgængelig elektronisk information, og inden længe ville man være totalt oversvømmet. Takket være en indsats som Dorthe Refslund Christensens er det nu også muligt for ikke-specialister at skabe sig et indblik i væsentlige aspekter af religionen Scientology: Hvad handler det 'i grunden om?'

Hvorvidt ph.d.-afhandlingen er 'korrekt' i den empiriske detalje må andre afgøre, der kan jeg ikke bidrage. Til gengæld er der i afhandlingen også en række teoretiske og metodiske nybrud, spørgsmål og overvejelser, som også kan og bør diskuteres. Nu er scientologer i grunde ikke så mange, men de er meget produktive, og derfor er dette i 
sandhed et studie i homo symbolicus' primære drift: Mening skal der til. I Scientology er der nok at øse af - der er viden om alting og modeller både 'af verden' og 'for verden'. Så det kosmologiske rum er (godt) fyldt ud. Handling og tolkning er der også basis for i Scientology's modeller 'for verden', herunder ikke mindst de terapeutiske aspekter, som behandles i afhandlingen. Grundfiguren i Scientology er, som Dorthe Refslund Christensen siger med L. Ron Hubbard: 'Man is miserable and something can be done about it'. Det har andre da også sagt, det er almindelig logik for profeter, og en sådan synes Hubbard også stærkt at ligne i den scientologiske hagiografi. Den mere interessante side af spørgsmålet er faktisk knyttet til indlejringen af denne grundtanke i udviklingen af Scientology efter 2. verdenskrig, fordi Scientology er så ny en religion, at den ikke kan undgå at forholde sig til tekniske og merkantile verdensbilleder: Frelsesagenten bliver 'E-meter'-apparatet, og stifteren bliver til et registreret varemærke. En næsten mod-intuitiv historie i forhold til den almindelige (senhellenistiske) opfattelse af forholdet mellem religiøs indsigt og verdens beskaffenhed.

Om begyndelsen: Mens Dorthe Refslund Christensen nok har en meget instruktiv historisk gennemgang af, hvordan Scientology bliver til, så mener hun ikke, at hun driver historisk-kritisk forskning, fordi "the aim is not to (re-) construct 'how it really happened' from a historic point of view, but rather to represent central ideas in the soteriological ideas of Hubbard as these are presented to and used by individuals and the Church today" (Rethinking Scientology, 52). Det er et lidt sært synspunkt, at sådan forskning ikke skulle være historisk-kritisk, eller at historisk-kritisk forskning kun er 'oprindelses'-forskning. Hun laver jo ganske almindelig religionshistorie, som jo netop er virknings- eller receptionshistorie - eller analyse, om man vil, af historisk givne selvforståelsesrepertoirer og -modaliteter. At hendes tilgang skal ses som noget nyt og være et særligt produkt af kognitiv teoretiseren er noget sludder. Dorthe Refslund Christensens begrundelse for ikke at vælge det, som hun forstår ved en historisk-kritisk tilgang knyttet til hendes speciale, hvor hun fandt ud af at "a historic-critical approach is not the right path to choose in that the historical correctness is of no importance to the Chruch or its individuals" (op.cit., 52). Selvfølgelig ikke. Men mon ikke Dorthe Refslund Christensen her har stirret sig blind på visse traditioner inden for teologisk forskning og ganske glemt, hvad religionshistorie er for noget. Jeg nævner det kun, fordi hun selv er religionshistoriker, og sådanne ved udmærket, at hinduer, muslimer og alle andre er ligeglade med, eller i stærk opposition til, hvad der er 'historisk korrekt'. Den slags studier har der ganske vist været masser af, men de er gået af mode for så lang tid siden, at Dorthe Refslund Christensen burde have bemærket det. Ikke mindst fordi Dorthe Refslund Christensens metode er historisk-kritisk uden omsvøb (hvordan skulle man ellers kunne skelne mellem f.eks. biografi og hagiografi?), hun bruger bare historisk-kritisk metode til mere end studiet af selve den tidligste genese. Men hvornår holder 'genesen' op? Hendes egen pointe er, at det gør den nok aldrig, og det har hun fuldstændig ret $\mathrm{i}$ - for en religions genese ophører først, når den dør ud (og så lever den måske endda videre ...). Hele afhandlingen er gennemgående historisk og kronologisk i sin logik og struktur, og Dorthe Refslund Christensen beskriver, forklarer 
og analyserer hvornår, hvordan og hvorfor L. Ron Hubbard tænkte, sagde og gjorde dette og hint, og det er jo netop hvad en historisk-kritisk analyse går ud på. Selv de såkaldte 'kognitive repræsentationer' er elementer i en historisk-kritisk analyse af tekster, som foregiver at handle om, hvad der foregik i L. Ron Hubbards hoved. Men det forudsætter et vist mål af teoretisk, epistemologisk og vel ikke mindst hermeneutisk naivitet at forestille sig, at disse tekster er direkte aftryk af den store mesters mentale tilstande.

Dorthe Refslund Christensen siger i sin indledningsforelæsning om sin 'pragmatiske' tilgang (til forskel fra en historisk-kritisk), "at det materiale, som hævdes at være Hubbards, analytisk må betragtes som Hubbards, hvis analysen skal give mening og skabe rammen for en forståelse af, hvordan individer, som er engageret i Scientology såvel som systemet selv opfatter og promoverer materialet". Selvfølgelig, det er god gammel (mindst siden Grønbech) 'indleven', 'epoché' eller 'agnostisk' fremlæggelse af 'insidersynspunkter' og i fuld overensstemmelse også med den antropologiske spørgen til 'intern forståelse' eller med en sociologisk fænomenologi. Det skal i øvrigt her præciseres, at religionshistorikere normalt ikke arbejder historisk-kritisk for at finde verden 'bag om' teksterne eller forestillingerne, men de arbejder historisk-kritisk med selve forestillingsuniverserne. Religionsvidenskabelige studier er i allerhøjeste grad studier af 'selvforståelse', så derfor forekommer visse udfald mod kritisk historisk analyse mere som retorisk end metodisk begrundede, f.eks.: "The construction of the history and conceptual development may be important when establishing Scientology as an object of study ... but it tends to construct a theology - and a theologism, according to the criticism of Boyer - which is nothing but a scholarly construction" (op.cit., 52f). Dette 'nothing but' kunne så ramme hele hendes projekt refleksivt, hvad det selvfølgelig ikke gør, men det afslører, at noget af det teoretiske apparat er retorisk af natur. Men det hænger også sammen med hendes stærke afhængighed af Pascal Boyer.

Boyers ideer og kritikker kan udmærket omsættes til og anvendes i religionsvidenskaben, men igen skal hans baggrund og ærinde tages i betragtning og kritisk vurderes i en mere udstrakt grad, end det er tilfældet i Rethinking Scientology. Mange af Boyers ideer er ret så geniale og tilsyneladende uproblematiske at anvende, men problemet er at man altid med et vokabular samtidig køber ontologier, epistemologier og teorier som kan, i det mindste, komplicere tingene. Det er også i et vist omfang sket for Dorthe Refslund Christensen. Jeg forstår fuldt ud hendes begejstring for at anvende kognitiv teori-dannelse, for dér synes vi at blive præsenteret for noget afgørende nyt; måske ligeså afgørende som da den franske sociologiske skole opfandt 'det sociologiske faktum'. Men det lukker også op for en lang række nye spørgsmål. For hvad er det i grunden, der er så kognitivt, når man som Dorthe Refslund Christensen arbejder med et kæmpe tekstkorpus? Og når man direkte undlader (eller undsiger sig) tekstteoretiske eller -analytiske teorier og metoder? Eller blot undlader at forklare sin undladelse.

Der er vel ingen tvivl om, at mennesker har mentale forestillinger (repræsentationer), men intersubjektivt kender vi dem kun som kulturelle produkter, f.eks. i sprog, der igen påvirker vore forestillinger osv. Ganske vist er det på visse niveauer muligt at 
iagttage og analysere før-kulturelle psykologiske reaktioner eller kognitive processer, men dette 'under-kulturelle' niveau sætter så at sige kun grænsebetingelserne for det, som så videre udgør vore mentale handlinger, og som er grundlaget for, at intersubjektivitet er en mulighed. Men på et hvilket som helst højere niveau bliver de socio-kulturelle produkter afgørende for repræsentationsformer og -funktioner. I Boyers teoridannelse tenderer kultur (dvs. betydningsproduktion) mod at blive et epifænomen, som ikke har nogen kausal forklaringskraft, og som derfor er uinteressant. Det er for så vidt forståeligt, når Boyers ærinde netop er at fremstille en 'stærk' psykologisk (kognitiv) teori om hukommelse og reproduktion af kultur. Kulturelle udtryk indgår således som materiale, men $\mathrm{i}$ en teori om noget ganske andet, for Boyers teoretiske objekt er de kognitive mekanismer og funktioner og betingelser for hukommelsesoptimalisering. Det viser sig, at visse typer af 'mod-intuitive' forestillinger er nemme at huske, at religiøse ideer er en klasse af sådanne, og at religion på sin vis kan forklares som resultat af en ganske naturlig menneskelig tilbøjelighed til at have sære ideer, der går imod de intuitive ontologier, som vi kognitivt er disponeret for. Altså er dette andet og mere end en eksplicit teori om religion. Derfor skal man være ganske bevidst om, hvad det er man tager med over $\mathrm{i}$ en religionsvidenskabelig analyse, når man $\mathrm{i} ø v$ rigt synes at Boyers bidrag kan være til nytte. Men det kunne så også fortjene en mere gennemgribende diskussion, såvel i Dorthe Refslund Christensens afhandling som i forskningen.

I sagen om L. Ron Hubbards genkommende 'representational redescriptions' (som det hedder med lån fra udviklingspsykologien) - der her lanceres som noget ganske nyt, må man vel sige at alle religioner er 'forestillinger genbeskrevet' - eller hvordan man nu skal oversætte det. Der er problemer her, bl.a. fordi 'representation' genkommer så mange steder med skiftende betydninger. Måske er der problemer, fordi begrebet 'meaning' helt forsvinder ud af Boyers meningsteoretiske 'nihilisme' - det er svært at sige, men det er en ganske alvorlig forståelsesmæssig forhindring, at relationerne mellem det kognitive og det kulturelt-symbolske er så uklare. Det skal Dorthe Refslund Christensen ikke lastes for, men det er et grundproblem, når der skal frem- og tilbageføres mellem tekstuelle udsagn og kognitive repræsentationer, der for det meste burde betyde noget i retning af 'mentale forestillinger'. Når der gøres så meget ud af, at ikke alle repræsentanter repræsenterer deres repræsentationer i overensstemmelse med et modsigelsesfrit dogmatisk system, så kunne det have været relevant med overvejelser over relationer mellem det, som er 'inden i' subjekterne og det, som er imellem dem. Men Dorthe Refslund Christensen har, med sin tilslutning til også Dan Sperber, indforskrevet sig til en materialistisk kulturopfattelse og en semantisk eliminativisme, hvor 'tegn' er 'nothing but' materielle objekter, som trigger kemisk-biologiske neuronale processer. Der er hos Sperber ikke plads til 'betydning', for det er endnu en præ-teoretisk 'folk notion', som vi var bedre foruden. Her er vi ved et generelt problem: Vel har Sperber, Boyer og andre sagt og skrevet meget, som er stærkt interessant og relevant for religionsvidenskaben, men det er, som nævnt, svært 'at købe hele pakken', fordi det har nogle konsekvenser, som man måske skal være klar over. Ikke mindst den i kognitivistiske kredse dominerende empiricisme og scientisme; en sine steder ret så 
problematisk naturvidenskabs-fascination, ifølge hvilken det synes mere videnskabeligt at beskæftige sig med ting, som er skjult i folks hoveder snarere end med noget, som er direkte tilgængeligt som f.eks. sproglige udtryk. Det er i grunden en underlig idé, at det skulle være lettere at finde ud af, hvad folk tænker, end hvad de siger. Det er nok fordi, man i de kredse grundlæggende betragter sprog som produkt af kognition, hvorimod 'kulturalister' (f.eks. antropologer) betragter intentionalitet, kultur og kognition som i høj grad 'language-driven'. Disse to grundholdninger er vel nærmest uforenelige, og mon ikke 'kognitivismen' som et nyt paradigme snarere vil danne menighed end enighed.

Fra psykologien har 'kognitivismen' arvet en individualistisk metodologi, som fokuserer på individets konstruktion af mentale modeller som subjektive repræsentationer primært af den fysiske omverden, og det er ikke altid så ligetil at anvende i analyser af kulturelle modeller som intersubjektive forestillinger konstrueret i relation til sociale omverdener, f.eks. religion. Og selv om de scientologiske forestillinger og modeller følger alle andre religiøse betydningskonstruktioner i deres struktur og skematik - som de 'kognitive' analyser kan påvise - så er de tilgængelige som scientologiske udelukkende i en kulturelt medieret form. Derfor bliver der problemer mellem analytiske og ontologiske niveauer, når tilgangen til de mentale repræsentationer går gennem de sproglige, symbolske og kulturelle produkter. Men denne 'metodestrid' mellem individualistisk og kollektivistisk (somme tider også kaldet 'holistisk') metodologi er ikke ny, vi skal bare huske, at den skal tænkes med. Direkte relateret til denne problematik er diskussion af det fænomen, som Dorthe Refslund Christensen kalder 'teologisme' - igen med reference til Pascal Boyer - som netop er tendensen til (også i forskningen) at forestille sig religiøse forklaringssystemer som fuldstændige 'worldviews', der er bestemmende (deduktivt, kausalt osv.) for individers kognition, adfærd osv., og at dette er fejlagtigt. Dorthe Refslund Christensen påpeger i sin indledningsforelæsning, at 'nyere kognitive teorier ... har påpeget, at der ikke eksisterer nogen automatik i relationerne mellem et religiøst system og dets individuelle participanter'. Fuldstændig korrekt, men det er ikke nogen mageløs ny opdagelse, for det er i grunden den problemfyldte 'theory and practice'-diskussion i ny forklædning, og den er behandlet ganske intensivt af andre, bl.a. i antropologiske kredse omkring 'cultural models and human motivation', i sociologien (hos f.eks. Pierre Bourdieu) og i diskursanalyse. Den har da også klare analogier til lingvistikkens problemer med relationerne mellem studier af sprogsystemer ('langue') og sprogbrug ('parole'). Der er al mulig grund til at hæfte sig ved denne problematik, som Dorthe Refslund Christensen netop gør, for den er også et hovedproblem i religionsvidenskaben. På det felt kunne religionsvidenskaben måske ligefrem bidrage til kognitionsforskningen med et væld af materiale. Men det er rigtigt, at megen tidligere religionsforskning har været 'teologistisk'; se blot den måde, som klassiske værker, som f.eks. Historia Religionum er bygget op på. Ikke desto mindre må man fastholde, at enhver betydningsproduktion kun kan være en sådan i relation til noget systemisk, hvad enten det drejer sig om et fodboldmål, 100 kroner eller en af L. Ron Hubbards mange ideer. Dorthe Refslund Christensen bemærker, at Hubbards 
repræsentationer såvel som Scientology Kirkens repræsentationer udgør det systemiske niveau over for individuelle scientologers repræsentationer. Men igen: er 'individernes repræsentationer' ikke også systemiske - uanset at de ikke udgør et perfekt dogmatisk system og snarere er at betegne som 'bricolage'? Ellers falder tesen om de religiøse forklaringers 'abduktive inferenspotentiale' og deres brugbarhed, for hvordan 'abducere' hvis ikke i (et) net af relationer? Og når det bemærkes så kraftigt, at L. Ron Hubbard ikke var systematisk og 'teologistisk', men at han derimod producerede vældige mængder af 'representational redescriptions', så er det heller ikke så nyt og mærkværdigt. Sådan har mange profeter gjort før ham, det hører med til deres karismatiske og liminelle kvaliteter i øvrigt, lige fra Zarathustra til Rudolf Steiner (som Dorthe Refslund Christensen kunne have inddraget, for der er ganske mange strukturelle ligheder mellem Antroposofi og Scientology) - og som Dorthe Refslund Christensen påpeger, så bidrager denne mangel på systematik til en høj grad af fleksibilitet i forestillingsrepertoirerne. Til gengæld standardiseres den rituelle praksis stadig mere, og vejen "til ultimativ åndelig frelse, Broen til Total Frihed, udgør da også et omfattende soteriologisk hierarki bestående af en lang række rituelle trin, som individet må afvikle i nøje fastlagt rækkefølge ...". Det er muligt, at Hubbard såvel som den enkelte scientolog ikke er 'teologistisk' systematiker, men der er nok 'noget' i de kollektive forestillingers verden, som betinger, at der systematiseres på livet løs, så snart der er mennesker til stede. Mennesker er meget produktive semantiske maskiner - de kan simpelthen ikke lade være. Så for min skyld måtte Dorthe Refslund Christensen gerne nedtone sin anti-systemiske hypotese på 'worldview'-siden, selv om den kan være nok så berettiget i en forskningshistorisk sammenhæng.

Et andet af Dorthe Refslund Christensens delprojekter omhandler forholdet mellem Dianetics som terapi og Scientology som religion. Til den ende inddrages en hel del relevant teori og forskning inden for medicinsk antropologi, og med reference til de kognitive teorier konkluderes, at religion og terapi involverer de samme kognitive mekanismer; religion er ikke nogen særlig 'mode of thought', som kan (eller bør) adskilles fra andre kulturelle aktiviteter. Ganske rigtigt og måske overflødigt, hvis ikke det var fordi, at det er en udbredt opfattelse, at religion er noget sui generis, en anden slags 'framework' osv. Dorthe Refslund Christensen er generelt rosværdigt omhyggelig med sine definitioner såsom 'terapi', 'sygdom', 'religion', 'kulturelt repertoire', 'soteriologi', og hvad der ellers er indsat i projektet. Der er masser af "relationer mellem terapi og religion i Scientologys soteriologiske ideer" - men det er der sandelig i stort set alle religioner, fra taoisme til Ndembu, fra Asklepios-kult til Islam. Her burde Dorthe Refslund Christensen nok have forholdt sig noget mere til forskningen i terapi og religion, nu er det som om den i det store hele ignoreres. Det er ellers nok at tage fat på fra shamanisme til karismatikere i Aalborg.

Et ganske særligt interessant afsnit omhandler L. Ron Hubbards kanonisering - om hvordan han bliver til noget 'ganz Anderes'. Som Dorthe Refslund Christensen siger: en de-humanisering og en tekstualisering med betoning af Hubbards særlige kvaliteter og en 'abstraktion af Hubbard fra menneske til Standard Teknologi' (de standardisere- 
de rituelle teknikker)"'. Det minder om kendte mønstre f.eks. som Buddhas i buddhismen, Jesus' i kristendommens historie eller om Muhammed som inspirator for et soteriologisk teknologisk system. Igen kunne Dorthe Refslund Christensen måske have trukket lidt mere på det almene religionsvidenskabelige materiale - det havde ikke gjort afhandlingen mindre interessant for ikke-specialister på Scientology. Men som det forholder sig nu, er der mange fængende analyser, der vidner om et stort og dybtgående arbejde. Som et ikke uvæsentligt resultat af Dorthe Refslund Christensens arbejde er Scientology blevet en del af religionsforskningens interessefelt. Hvordan Scientology så vil have det med det $\mathrm{i}$ fremtiden, er en anden sag, men foreløbig viser Dorthe Refslund Christensen at den rigtige feltforsker godt kan lave et ordentligt studium dér, hvor andre ikke har kunnet. Dermed har hun også demonstreret noget af en mere upåagtet, men absolut (for hvem det måtte angå) uundværlig forskningskompetence: evnen til feltarbejde. I en verden hvor religion (nok alligevel) ikke forsvinder, er der mere end god brug for forskere også med særlige menneskelige kvaliteter. 